\title{
The wonder of RNA: a personal reflection of the last 20 years
}

\author{
PHILIP C. BEVILACQUA \\ The Pennsylvania State University, University Park, Pennsylvania 16802, USA
}

I remember the RNA journal starting out during the time I was a postdoc in the Cech lab. One day Tom Cech walked into the lunchroom and asked how we thought such a journal would be received, and if there might be sufficient interest in the community to sustain it. This was in 1994 and the first issue of the journal was published in March of 1995. I feel lucky to have worked my entire career in the RNA field beginning with graduate research with Doug Turner, followed by postdoc research with Tom, and continuing on with my research as a faculty member at Penn State. The RNA field has had countless advances over the last two decades, and the fledgling journal that Tom helped found in the mid1990s is now one of the leading places to publish in our field.

As I look back over the last two decades and ponder the most significant advances in the RNA field, I find myself drawn to the new discoveries - discovery of RNA interference (RNAi) by Ambros, Fire, and Mello; of countless riboswitches and ribozymes by Breaker, Henkin, and Luptak; and of myriad RNA elements involved in regulating gene expression. One common thread to these advances has been the role played by sequencing technology. Indeed, new technologies have heralded advances throughout the history of RNA research. The human genome project began in 1990 and was completed in the early 2000s. This was a heroic feat, one that took over a decade to accomplish and that was driven by advances in sequencing technology. In recent years, impacts of next-generation sequencing technologies have been massive. Plans to sequence 1000 different human genomes have been pursued and completed. Thousands of different bacteria species have been sequenced, and now over a hundred different plant species have been sequenced. In one-upmanship 1001 strains of the reference plant Arabidopsis thaliana are being sequenced. This plethora of genomic sequences means availability of a plethora of RNA sequences. One astonishing revelation of the ENCODE project is that upwards of $75 \%$ of the human genome is transcribed, while only $1 \%-2 \%$ of the genome codes for proteins. A vast array of non-coding RNA awaits characterization!

\footnotetext{
Corresponding author: pcb5@psu.edu

Article and publication date are at http://www.rnajournal.org/cgi/doi/10. 1261/rna.050401.115. Freely available online through the RNA Open Access option.
}

The invention of next-generation sequencing technologies is fueling some of the most exciting questions in RNA biology. For instance, "How do single nucleotide polymorphisms (SNPs) lead to changes in RNA folding which can cause a disease?" Alain Laederach and co-workers coined the term RiboSNitch for such SNPs or functional mutations. Work from his lab and the Chang lab is revealing relationships between RiboSNitches and disease, which will find applications in personalized medicine. Another question is "Is RNA covalently modified post-transcriptionally much more extensively than currently appreciated?" Work from the He, Gilbert, Fink, and Regev labs have begun to show that the answer is yes, and the biological consequences and effects on RNA structure are being pursued. Another key question is "How does RNA fold across an entire genome and how does that change with environmental conditions?" Recently, our lab in collaboration with Sally Assmann's lab developed the method of Structure-seq, which allows the structure of all RNAs in a transcriptome to be assessed in vivo. To date, we have applied the method to Arabidopsis using DMS as the probe, but it can be expanded to other probes and applied to other organisms. Insights into relationships between RNA structure and translation, splicing, alternative polyadenylation, and stress have been gained. Similar genome-wide methods have been reported by the Chang, McManus, Weeks, and Weissman labs and applied to yeast, humans, and viruses. These studies have begun to reveal insights into RNA folding and unfolding in vivo, variation of RNA secondary structure in a human family, and correlations between RNA structure and protein structure. Another important area is understanding how in vivo conditions-crowding, metabolites, and cellular ionic conditions-influence RNA folding and function: "What are the thermodynamics and kinetics for RNA folding under these conditions?" and "Are mechanisms of ribozymes and riboswitches different under such conditions?" Several groups, including the Harris, Jankowsky, and Ferré-D’Amaré labs, have recently applied next-gen sequencing to the characterization of ribozymes, which has led to deep insights. And one of the

(C) 2015 Bevilacqua This article, published in $R N A$, is available under a Creative Commons License (Attribution-NonCommercial 4.0 International), as described at http://creativecommons.org/licenses/by-nc/4.0/. 
biggest questions in all of science, being approached by a number of groups including the Szostak and Joyce labs, is "How did life begin and what role did RNA or RNA-like molecules play?"

Time and again the RNA field has surprised us. The last two decades have been no exception. Remarkable characterization of RNA has been accomplished, including a flood of new RNA structures and deep insights into the mechanisms of ribozymes and riboswitches. Novel roles for the metal ions and nucleobases in RNA chemistry have been uncovered and probed by experiment and theory. In recent years, the field has caught fire again with the ability to ask questions in new and exceptionally powerful ways. Next-generation sequencing in particular allows inquiry into the base pairing status of every nucleotide in an RNA transcriptome in a single experiment. What I look forward to over the next 20 years are the new discoveries none of us have anticipated. These will almost certainly include additional examples of our favorite RNA classes_ — such as additional ribozymes and riboswitches-but it will also include surprises, with altogether new classes of RNA. Uncovering these hidden RNAs will provide systems for structural and biophysical characterization and help us understand how nature works and what roles RNA plays as both an informatic and functional molecule. I'm reminded of Dr. Seuss, "Oh the sea is so full of a number of fish. If a fellow is patient, he might get his wish. And that's why I think that I'm not such a fool when I sit here and fish in McElligot's Pool."

${ }^{1}$ Dr. Seuss. 1947. McElligot's Pool. Random House, New York. 

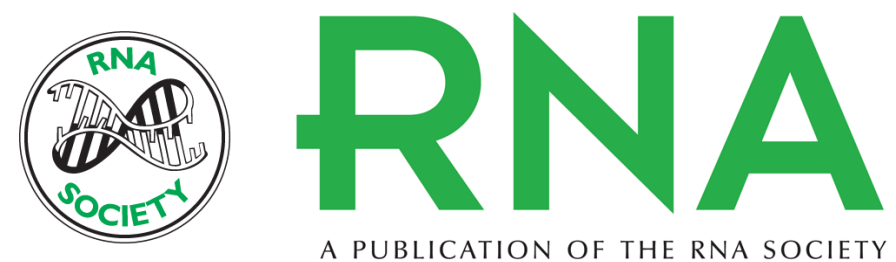

A PUBLICATION OF THE RNA SOCIETY

\section{The wonder of RNA: a personal reflection of the last 20 years}

Philip C. Bevilacqua

RNA 2015 21: 515-516

Open Access Freely available online through the RNA Open Access option.

Creative This article, published in RNA, is available under a Creative Commons License Commons (Attribution-NonCommercial 4.0 International), as described at License http://creativecommons.org/licenses/by-nc/4.0/.

Email Alerting Receive free email alerts when new articles cite this article - sign up in the box at the Service top right corner of the article or click here.

To subscribe to $R N A$ go to:

http://rnajournal.cshlp.org/subscriptions

(C) 2015 Bevilacqua; Published by Cold Spring Harbor Laboratory Press for the RNA Society 